Article

\title{
Relationship between Bone Health Biomarkers and Cardiovascular Risk in a General Adult Population
}

\author{
Cristina Vassalle *, Laura Sabatino, Pietro Di Cecco, Maristella Maltinti, Rudina Ndreu, \\ Silvia Maffei and Alessandro Pingitore \\ Fondazione CNR-Regione Toscana G Monasterio and Istituto di Fisiologia Clinica, CNR via Moruzzi 1, \\ I-56124 Pisa, Italy; laura.sabatino@ifc.cnr.it (L.S.); pietro.dicecco@ftgm.it (P.D.C.); maristella@ftgm.it (M.M.); \\ rudina.ndreu@ifc.cnr.it (R.N.); silvia.maffei@ftgm.it (S.M.); pingi@ifc.cnr.it (A.P.) \\ * Correspondence: cristina.vassalle@ftgm.it; Tel.: +39-050-3153-525; Fax: +39-050-315-2166
}

Received: 8 September 2017; Accepted: 21 October 2017; Published: 24 October 2017

\begin{abstract}
Purpose/Introduction: Osteoporosis (OP) and cardiovascular (CV) disease emerge as closely related conditions, showing common risk factors and/or pathophysiological mechanisms. The aim of this study was to evaluate the association between bone health markers (BHM) and individual $\mathrm{CV}$ risk factors and overall $\mathrm{CV}$ risk (FRAMINGHAM-FRS, and PROCAM scores) in a general adult population. Methods: In 103 subjects (21 males; age: $56 \pm 12$ years), vitamin $\mathrm{D}(25(\mathrm{OH}) \mathrm{D})$, osteocalcin $(\mathrm{OC})$, bone alkaline phospatase (BALP), procollagen I aminoterminal propeptide (P1NP), CTx-telopeptide, as well clinical history and life style were evaluated. Results: Aging $(p<0.001)$ and glycemia $(p<0.05)$ emerged as independent $25(\mathrm{OH}) \mathrm{D}$ predictors. Aging $(p<0.001)$, male sex $(p<0.05)$, and obesity $(p<0.05)$ represented independent OC determinants. Aging $(p<0.05)$ was the only independent BALP determinant. After multivariate adjustment, low $25(\mathrm{OH}) \mathrm{D}(<20 \mathrm{ng} / \mathrm{mL})($ Odds ratio OR $(95 \%$ confidence intervals $\mathrm{CI}))(5(1.4-18) p<0.05)$ and elevated OC ( $>75$ th percentile- $16.6 \mathrm{ng} / \mathrm{mL})(6.7(1.9-23.8) p<0.01)$ were found to be significant FRS predictors, while subjects with elevated OC and/or BALP $(>75$ th percentile-9.8 $\mu \mathrm{g} / \mathrm{L})$ showed a higher CV risk as estimated by PROCAM $(3.6(1.2-10.7) p<0.05)$. CTx and P1NP did not significantly correlate with $\mathrm{CV}$ risk factors or scores. Conclusion: As we go further into bone and $\mathrm{CV}$ physiology, it is evident that a close relationship exists between these diseases. Further studies are needed to investigate mechanisms by which bone turnover markers are related to metabolic risk and could modulate CV risk. This knowledge may help to develop possible multiple-purpose strategies for both CV disease and OP prevention and treatment.
\end{abstract}

Keywords: cardiovascular risk; vitamin D; bone turnover biomarkers; FRAMINGHAM score; PROCAM score

\section{Introduction}

Both osteoporosis (OP) and cardiovascular (CV) disease are relevant public health problems, leading to increased morbidity and mortality as well as elevated clinical and economic burden [1]. Recent data suggest the relationship between osteoporosis and CV disease through mechanisms that have not been fully elucidated, but are likely related to common risk factors, common pathophysiological mechanisms, or both [1]. Bone health markers (BHM) showed correlation with biomarkers of subclinical atherosclerotic manifestation, $\mathrm{CV}$ risk factors and events [1]. In particular, osteocalcin (OC), a bone matrix protein produced by osteoblasts, has been investigated as a hormone affecting glucose metabolism and fat mass [2]. Moreover, several evidences suggest the relationship between low 25-hydroxyvitamin $\mathrm{D}(25(\mathrm{OH}) \mathrm{D})$ and different cardiovascular determinants, particularly aging, hypertension, diabetes, obesity, and metabolic syndrome [3-5]. Low 25(OH)D has been related to higher $\mathrm{CV}$ risk and $\mathrm{CV}$ and overall mortality through meta-analysis studies $[6,7]$. 
In recent years, different scales-including the PROCAM and the FRAMINGHAM (FRS)been developed to estimate the 5-10-year risk in asymptomatic population [8,9]. However, BHM have never been evaluated according to global risk.

Thus, the aim of the present study is to evaluate the associations between biochemical BHM, individual $\mathrm{CV}$ risk factors, and $\mathrm{CV}$ risk scores in a general adult population.

\section{Material and Methods}

\subsection{Subjects and Cardiovascular Risk Scores}

The study included a general population of 103 subjects (21 males; mean age (SD): 56 (12) years) including adult volunteers and hospital outpatients of our Endocrinological Ambulatory in Pisa, Italy (latitude $43^{\circ} \mathrm{N}$ ). At enrolment, each participant was interviewed about CV disease familiarity, clinical history, previous CV events, and lifestyle habits. Hypertension was defined if the average of recorded values was higher than $140 / 90 \mathrm{mmHg}$ or in the presence of antihypertensive treatment. For each patient, body mass index (BMI) was calculated (obesity if BMI $>30 \mathrm{~kg} / \mathrm{m}^{2}$ ). An altered lipid status was considered in the case of total cholesterol concentration $\geq 200 \mathrm{mg} / \mathrm{dL}$ ( $5.18 \mathrm{mmol} / \mathrm{L})$, or triglyceride concentration $\geq 150 \mathrm{mg} / \mathrm{dL}(1.69 \mathrm{mmol} / \mathrm{L})$, or current use of lipid-lowering drugs. Type 2 diabetes was defined if twice-fasting plasma glucose was $>126 \mathrm{mg} / \mathrm{dL}(7 \mathrm{mmol} / \mathrm{L})$ or in case of use of antidiabetic treatment. All subjects were free from acute or chronic inflammatory disease, significant renal impairment, immunological disease, and history or evidence of malignancy.

The FRS risk score predicts the 10-year risk of developing CV events, including coronary heart disease, stroke, peripheral artery disease, or heart failure. This sex-specific score considers age, total and high-density lipoprotein cholesterol, systolic blood pressure, treatment for hypertension, smoking, and diabetes. A score $<10 \%$ is considered at low risk, $10-20 \%$ intermediate risk, and $>20 \%$ high risk of CV events [8].

The PROCAM risk score considers age, LDL cholesterol, smoking, HDL cholesterol, systolic blood pressure, family history of premature myocardial infarction, diabetes mellitus, and triglycerides, in addition to previous coronary events [9]. A score lower than $10 \%$ is considered low, $10-20 \%$ intermediate, and higher than $20 \%$ as high for the 10 -year risk of $\mathrm{CV}$ events.

We have complied with the World Medical Association Declaration of Helsinki regarding ethical conduct of research involving human subjects.

\subsection{Laboratory Measurements}

After an overnight fast, blood samples were drawn from the left antecubital vein, and centrifuged within $15 \mathrm{~min}$ after blood collection at $2500 \times \mathrm{g}$ for $15 \mathrm{~min}$ at $4{ }^{\circ} \mathrm{C}$. Serum samples were immediately stored at $-80^{\circ} \mathrm{C}$ for less than one week before subsequent analysis. $25(\mathrm{OH}) \mathrm{D}, \mathrm{OC}$, and bone alkaline phosphatase (BALP) were analyzed on an automated LIAISON (Diasorin, Salluggia, Vicenza, Italy), while procollagen type I N-terminal propeptide (P1NP) and C-terminal telopeptide (CTX) were also measured on a Cobas e411 analyzer (Roche Elecsys, Indianapolis, IN, USA) [3,10]. As we previously observed, 25(OH)D samples were extremely stable for light, temperature, and storage, without requiring special transport or precautions [3]. 25(OH)D was scored according to daylight saving time (DST), which is the is the practice of setting the clocks forward 1 hour from standard time during the summer months, and back again in the fall. Hemolyzed samples were excluded and withdrawal was repeated, as OC may decrease with hemolysis [10].

In addition, glycemia (fluoride-containing tubes), insulin (INS), lipid profile (total cholesterol, TotCH; triglycerides, TG; high density lipoproteins, HDL), and hsC-reactive protein (CRP, serum) were measured with a standard clinical chemistry laboratory analyzer (UniCel DxC 600 Chemistry Analyzer, Beckman, Brea, CA, USA). Levels of low-density lipoproteins (LDL) were calculated with the Friedewald equation. 


\subsection{Statistical Analysis}

Continuous variables with little-to-mild skewness were summarized as means $\pm S D$, while data were expressed as medians (min-max) for variables with a skewed distribution, or percentages for categorical variables. Comparisons were made by means of the two-sample Student's $t$-test for continuous variables and by Chi-square analysis for categorical variables. Comparisons among different groups were performed by using ANOVA test and $p$ for trend reported. Regression analysis with Pearson's test was also used to evaluate the relationship between the two continuous variables.

Owing to skewness, log transformations of glycemia, INS, TG, OC, CTx, and CRP were used for statistical analyses. Then, log-transformed values were back-transformed for data presentation.

Univariate predictors with a $p$ value $\leq 0.5$ were entered into a multivariate regression analysis (BHM as the dependent variables, and significant parameters as the independent variables to determine independent predictors for each BHM). Additionally, a logistic regression analysis was used to estimate the independent association among BHM with the composite scores (FRS, PROCAM), after adjusting for potential confounders that were not part of the scores (CRP and obesity), but can increase CV risk and may be related to BHM.

A $p$-value $<0.05$ was chosen as the level of significance.

\section{Results}

\subsection{Characteristics of Subjects}

Demographic and clinical characteristics of the subject population, lifestyle factors, and risk score levels are reported in Table 1. The studied population included 103 subjects (21 males; mean age (SD): 56 (12) years). The whole population included 11 obese subjects and 19 current smokers, as well as 48 subjects with dyslipidemia, 30 with hypertension, and 10 with Type 2 diabetes.

Table 1. Demographic, clinical and biochemical characteristics of the studied subjects.

\begin{tabular}{|c|c|}
\hline Parameters & Values \\
\hline $\mathrm{n}$ & 103 \\
\hline Age (years) & $56 \pm 12$ \\
\hline Males, n (\%) & $21(20)$ \\
\hline Hypertension, n (\%) & $30(29)$ \\
\hline Diabetes, n (\%) & $10(10)$ \\
\hline Dyslipidemia, n (\%) & $48(47)$ \\
\hline Current smokers, $\mathrm{n}(\%)$ & $19(19)$ \\
\hline Obesity, n (\%) & $11(11)$ \\
\hline Body Mass Index $\left(\mathrm{Kg} / \mathrm{m}^{2}\right)$ & $24.8 \pm 4.6$ \\
\hline Total cholesterol (mg/dL) & $207 \pm 36$ \\
\hline HDL cholesterol (mg/dL) & $62 \pm 16$ \\
\hline Triglycerides (mg/dL), median (min-max) & $89(39-299)$ \\
\hline LDL cholesterol (mg/dL) & $125 \pm 30$ \\
\hline Glycemia (mg/dL), median (min-max) & $88(73-161)$ \\
\hline Insulin $(\mathrm{mUI} / \mathrm{mL}) *$, median (min-max) & $4(1-18)$ \\
\hline Systolic blood pressure $(\mathrm{mmHg})$ & $125 \pm 18$ \\
\hline Diastolic blood pressure (mmHg) & $75 \pm 9$ \\
\hline C-reactive protein (mg/dL), median (min-max) & $0.14(0.02-3.1)$ \\
\hline 25-hydroxyvitamin $\mathrm{D}(\mathrm{ng} / \mathrm{mL})$ & $23 \pm 10$ \\
\hline Osteocalcin (ng/mL), median (min-max) & $11(5-32)$ \\
\hline Bone alkaline phosphatase (mg/L) & $8 \pm 3.6$ \\
\hline Amino-terminal propeptide (mg/L) & $32.4 \pm 15.5$ \\
\hline C-terminal telopeptide (ng/mL), median (min-max) & $0.2(0.1-0.8)$ \\
\hline
\end{tabular}

\footnotetext{
* data available in 65 subjects. Values are mean \pm DS, unless otherwise specified.
} 
According to the baseline cardiovascular risk estimation, 86 subjects $(84 \%)$ were classified as low risk, and $17(16 \%)$ as intermediate risk with regard to FRS. Risk group distribution according to PROCAM was $85(82 \%), 15(15 \%)$, and $3(3 \%)$ for the low-, intermediate-, and high-risk groups, respectively.

\subsection{Correlation between Bone Health Biomarkers}

The correlation among BHM (OC, BALP; P1NP, CTx, 25(OH)D) is reported in Table 2.

Table 2. Correlation between bone health biomarkers.

\begin{tabular}{ccccc}
\hline & OC & BALP & P1NP & CTx \\
\hline 25(OH)D & $\mathrm{r}=-0.3 p<0.01$ & $\mathrm{r}=-0.27 p<0.01$ & $\mathrm{r}=-0.1 p=\mathrm{ns}$ & $\mathrm{r}=-0.15 p=\mathrm{ns}$ \\
OC & & $\mathrm{r}=0.66 p<0.001$ & $\mathrm{r}=0.53 p<0.001$ & $\mathrm{r}=0.54 p<0.001$ \\
BALP & & & $\mathrm{r}=0.45 p<0.001$ & $\mathrm{r}=0.45 p<0.001$ \\
P1NP & & & & $\mathrm{r}=0.82 p<0.001$ \\
\hline
\end{tabular}

$25(\mathrm{OH}) \mathrm{D}=$ vitamin $\mathrm{D} . \mathrm{OC}=$ osteocalcin. $\mathrm{BALP}=$ bone alkaline phosphatase. $\mathrm{P} 1 \mathrm{NP}=$ procollagen type I N-terminal propeptide. $\mathrm{CTx}=\mathrm{C}$-terminal telopeptide.

$25(\mathrm{OH}) \mathrm{D}$ inversely correlated with OC $(\mathrm{r}=-0.30, p<0.01)$ and BALP $(\mathrm{r}=-0.27, p<0.01)$ (Table 2). All the other BHM directly correlated with each other. Specifically, OC directly correlated with BALP $(\mathrm{r}=0.66, p<0.001), \mathrm{P} 1 \mathrm{NP}(\mathrm{r}=0.53, p<0.001)$, and CTx $(\mathrm{r}=0.54, p<0.001)$. Moreover, P1NP directly correlated with BALP $(\mathrm{r}=0.45, p<0.001)$, CTx with BALP $(\mathrm{r}=0.45, p<0.001)$, and P1NP with CTx $(\mathrm{r}=0.82, p<0.001)($ Table 2$)$.

\subsection{Correlation between Bone Health Biomarkers and CV Risk Factors}

\subsection{1. $25(\mathrm{OH}) \mathrm{D}$}

$25(\mathrm{OH}) \mathrm{D}$ inversely correlated with glycemia $(\mathrm{r}=-0.32, p<0.01)$ and aging $(\mathrm{r}=-0.47, p<0.001)$. Moreover, 25(OH)D levels were higher in females (24 \pm 9 versus $19 \pm 11 \mathrm{ng} / \mathrm{mL}, p<0.05)$, and lower in subjects with diabetes (14 \pm 9 versus $24 \pm 10 \mathrm{ng} / \mathrm{mL}, p<0.01)$, hypertension (19 \pm 8 versus $25 \pm 10 \mathrm{ng} / \mathrm{mL}, p<0.01)$, and dyslipidemia $(21 \pm 9$ versus $26 \pm 11 \mathrm{ng} / \mathrm{mL}, p<0.05)$, with respect to those without (Tables 3 and 4 ). Levels of 25 -OHD were found to be sufficient $(\geq 30 \mathrm{ng} / \mathrm{mL}$ ) only in 21 $(20 \%)$ subjects. $25(\mathrm{OH}) \mathrm{D}$ levels were higher during the DST period, although this difference did not reach statistical significance ( $25 \pm 8$ versus $22 \pm 11 \mathrm{ng} / \mathrm{mL}, p=0.2$ ).

In a multiple regression model adjusted for the variables, aging ( $t$-value $-3.9, p<0.001)$ and glycemia ( $t$-value $-2.2, p<0.05)$ emerged as the only significant independent predictors for $25(\mathrm{OH}) \mathrm{D}$.

Levels of 25(OH)D were also reduced in subjects with higher FRS ( $16 \pm 8$ versus $25 \pm 10 \mathrm{ng} / \mathrm{mL}$, $p<0.01$ ) and PROCAM scores (12 \pm 7 versus $19 \pm 9$ and $25 \pm 10 \mathrm{ng} / \mathrm{mL}, p<0.05$ for trend) (Figure 1 , panel a). 
Table 3. Correlation between HBM and continuos variables.

\begin{tabular}{|c|c|c|c|c|c|c|c|c|c|c|c|}
\hline & Age & BMI & Glycemia & Insulin * & $\begin{array}{c}\text { Total } \\
\text { Cholesterol }\end{array}$ & HDL & TG & LDL & CRP & SBP & DBP \\
\hline & Years & $\mathrm{Kg} / \mathrm{m}^{2}$ & $\mathrm{mg} / \mathrm{dL}$ & $\mathrm{mUI} / \mathrm{mL}$ & $\mathrm{mg} / \mathrm{dL}$ & $\mathrm{mg} / \mathrm{dL}$ & $\mathrm{mg} / \mathrm{dL}$ & $\mathrm{mg} / \mathrm{dL}$ & $\mathrm{mg} / \mathrm{dL}$ & $\mathrm{mmHg}$ & $\mathrm{mmHg}$ \\
\hline $\begin{array}{c}\text { VitD } \\
(\mathrm{ng} / \mathrm{mL})\end{array}$ & $\begin{array}{c}\mathrm{r}=-0.47 \\
p<0.001\end{array}$ & $\mathrm{r}=-0.17, \mathrm{~ns}$ & $\begin{array}{c}\mathrm{r}=-0.32 \\
p<0.01\end{array}$ & $\begin{array}{c}\mathrm{r}=-0.07 \\
\mathrm{~ns}\end{array}$ & $\mathrm{r}=0.02, \mathrm{~ns}$ & $\mathrm{r}=0.2, \mathrm{~ns}$ & $\mathrm{r}=-0.16, \mathrm{~ns}$ & $\mathrm{r}=0.01, \mathrm{~ns}$ & $\mathrm{r}=0.13, \mathrm{~ns}$ & $\mathrm{r}=0.1, \mathrm{~ns}$ & $\mathrm{r}=0.03, \mathrm{~ns}$ \\
\hline $\begin{array}{c}\mathrm{OC} \\
(\mathrm{ng} / \mathrm{mL})\end{array}$ & $\begin{aligned} \mathrm{r} & =0.37 \\
p & <0.001\end{aligned}$ & $\mathrm{r}=0.02, \mathrm{~ns}$ & $\mathrm{r}=0.18, \mathrm{~ns}$ & $\begin{array}{l}\mathrm{r}=0.32 \\
p<0.01\end{array}$ & $\mathrm{r}=0.1, \mathrm{~ns}$ & $\mathrm{r}=-0.15, \mathrm{~ns}$ & $\mathrm{r}=0.1, \mathrm{~ns}$ & $\mathrm{r}=0.05, \mathrm{~ns}$ & $\mathrm{r}=0.04, \mathrm{~ns}$ & $\mathrm{r}=0.06, \mathrm{~ns}$ & $\mathrm{r}=0.03, \mathrm{~ns}$ \\
\hline $\begin{array}{c}\text { BALP } \\
(\mathrm{mg} / \mathrm{L})\end{array}$ & $\begin{array}{r}\mathrm{r}=0.3 \\
p<0.01\end{array}$ & $\mathrm{r}=0.002, \mathrm{~ns}$ & $\mathrm{r}=0.18, \mathrm{~ns}$ & $\begin{array}{l}\mathrm{r}=0.26 \\
p<0.05\end{array}$ & $\mathrm{r}=0.13, \mathrm{~ns}$ & $\mathrm{r}=-0.13, \mathrm{~ns}$ & $\mathrm{r}=0.02, \mathrm{~ns}$ & $\mathrm{r}=0.17, \mathrm{~ns}$ & $\mathrm{r}=0.07, \mathrm{~ns}$ & $\mathrm{r}=0.18, \mathrm{~ns}$ & $\mathrm{r}=0.1, \mathrm{~ns}$ \\
\hline $\begin{array}{l}\text { P1NP } \\
(\mathrm{mg} / \mathrm{L})\end{array}$ & $\mathrm{r}=0.05, \mathrm{~ns}$ & $\mathrm{r}=0.002, \mathrm{~ns}$ & $\begin{array}{c}\mathrm{r}=-0.13 \\
\mathrm{~ns}\end{array}$ & $\begin{array}{c}\mathrm{r}=-0.12 \\
\mathrm{~ns}\end{array}$ & $\mathrm{r}=0.12, \mathrm{~ns}$ & $\mathrm{r}=0.02, \mathrm{~ns}$ & $\mathrm{r}=0.07, \mathrm{~ns}$ & $\mathrm{r}=0.13, \mathrm{~ns}$ & $\mathrm{r}=0.05, \mathrm{~ns}$ & $\mathrm{r}=-0.12, \mathrm{~ns}$ & $\mathrm{r}=0.02, \mathrm{~ns}$ \\
\hline $\begin{array}{c}\mathrm{CTx} \\
\text { (ng/mL) }\end{array}$ & $\mathrm{r}=0.1, \mathrm{~ns}$ & $\mathrm{r}=0.01, \mathrm{~ns}$ & $\mathrm{r}=0.03, \mathrm{~ns}$ & $\mathrm{r}=0.08, \mathrm{~ns}$ & $\mathrm{r}=0.2, \mathrm{~ns}$ & $\mathrm{r}=0.01, \mathrm{~ns}$ & $\mathrm{r}=0.03, \mathrm{~ns}$ & $\mathrm{r}=0.17, \mathrm{~ns}$ & $\mathrm{r}=0.1, \mathrm{~ns}$ & $\mathrm{r}=0.01, \mathrm{~ns}$ & $\mathrm{r}=0.09, \mathrm{~ns}$ \\
\hline
\end{tabular}

* data available in 65 subjects. $n s=$ not significant. 


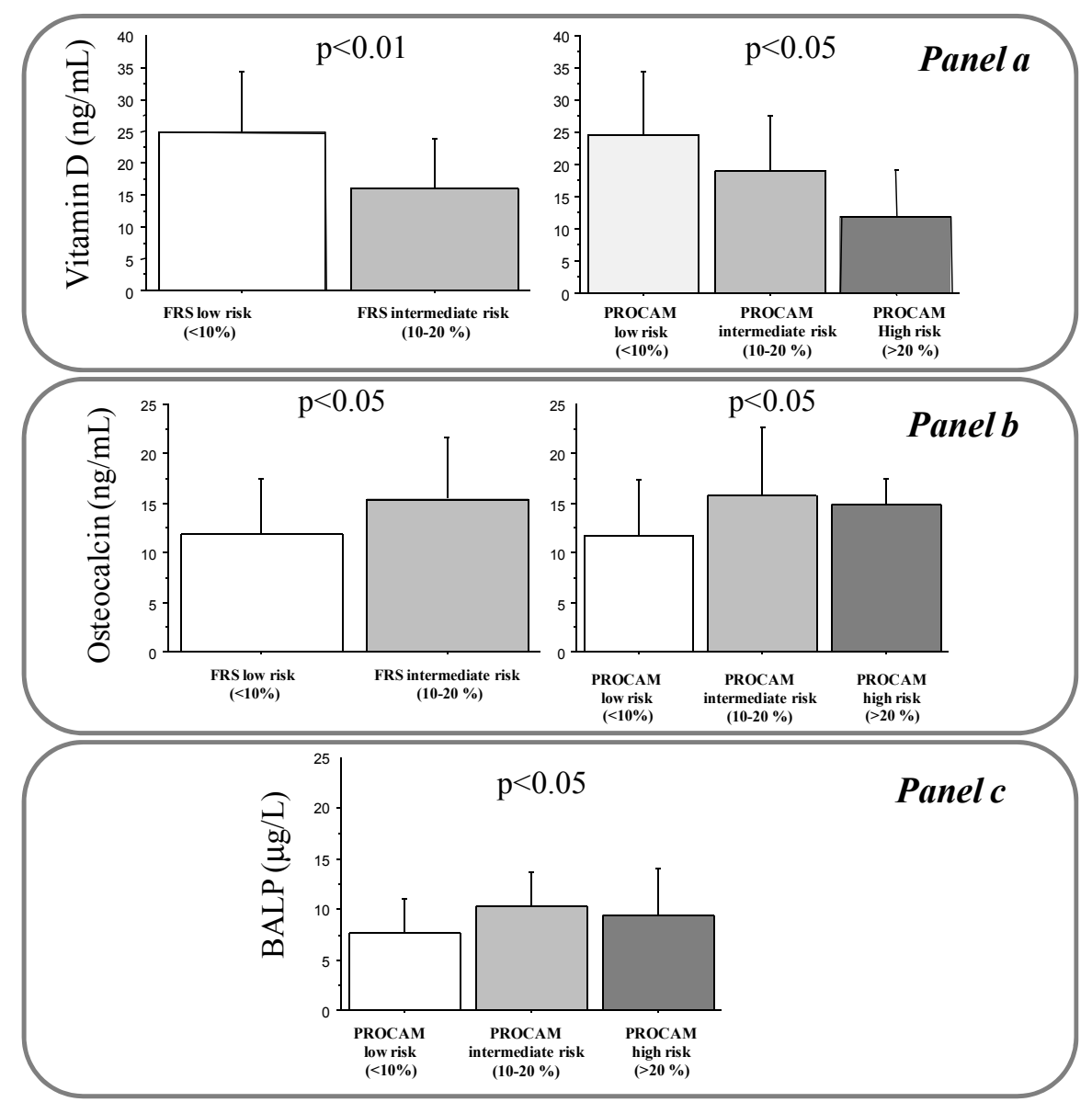

Figure 1. Levels of 25(OH)D (panel a), OC (panel b), and BALP (Panel c) according to FRS and PROCAM risk stratification in the studied population. $p$ for trend.

\subsubsection{OC}

OC positively correlated with aging $(\mathrm{r}=0.37, p<0.001)$ and INS $(\mathrm{r}=0.32, p<0.01)$ (Table 3$)$. Moreover, $\mathrm{OC}$ levels were higher in men than women ( $15 \pm 5.8$ versus $11.7 \pm 5.8 \mathrm{ng} / \mathrm{mL}, p<0.05)$, and lower in obese subjects $(8.6 \pm 3.3$ versus $12.8 \pm 6 \mathrm{ng} / \mathrm{mL}, p<0.05)$, and during the DST period versus no-DST (11 \pm 5 versus $13.3 \pm 6.3 \mathrm{ng} / \mathrm{mL}, p \leq 0.05$ ) (Table 4). Multiple regression analysis revealed that aging ( $t$-value 3.1, $p<0.001)$, male sex ( $t$-value $2.4, p<0.05)$, and obesity ( $t$-value $-2.5, p<0.05)$ represented independent determinants for OC. However, OC levels increased according to increased FRS (11.8 \pm 5.7 versus $15.4 \pm 6.2 \mathrm{ng} / \mathrm{mL}, p<0.05)$ and PROCAM risk stratification (11.7 \pm 5.6 versus $15.8 \pm 6.8$ and $15 \pm 2.6 \mathrm{ng} / \mathrm{mL}, p<0.05$ for trend) (Figure 1, panel b).

Table 4. Correlation between HBM and categorical variables.

\begin{tabular}{lccccccc}
\hline & Males & \multicolumn{1}{c}{ Diabetes Hypertension } & Dyslipidemia & Smoking Habit & Obesity & DST \\
\hline VitD $(\mathrm{ng} / \mathrm{mL})$ & $-^{*}$ & $-{ }^{* *}$ & $-* *$ & $-* *$ & $\mathrm{~ns}$ & $\mathrm{~ns}$ & $\mathrm{~ns}$ \\
OC $(\mathrm{ng} / \mathrm{mL})$ & $+^{*}$ & $\mathrm{~ns}$ & $\mathrm{~ns}$ & $\mathrm{~ns}$ & $\mathrm{~ns}$ & $-^{*}$ & $-^{*}$ \\
BALP $(\mathrm{mg} / \mathrm{L})$ & $\mathrm{ns}$ & $\mathrm{ns}$ & $\mathrm{ns}$ & $+^{*}$ & $\mathrm{~ns}$ & $\mathrm{~ns}$ & $\mathrm{~ns}$ \\
P1NP $(\mathrm{mg} / \mathrm{L})$ & $\mathrm{ns}$ & $\mathrm{ns}$ & $\mathrm{ns}$ & $\mathrm{ns}$ & $\mathrm{ns}$ & $\mathrm{ns}$ & $-^{* *}$ \\
CTx $(\mathrm{ng} / \mathrm{mL})$ & $\mathrm{ns}$ & $\mathrm{ns}$ & $\mathrm{ns}$ & $\mathrm{ns}$ & $\mathrm{ns}$ & $\mathrm{ns}$ & $-^{*}$ \\
\hline
\end{tabular}




\subsubsection{BALP}

BALP directly correlated with aging $(\mathrm{r}=0.3, p<0.01)$ and INS $(\mathrm{n}=65, \mathrm{r}=0.26, p<0.05)$ (Table 3). Moreover, BALP levels were higher in dyslipidemic subjects ( $8.8 \pm 3.8$ versus $7.4 \pm 3.2 \mu \mathrm{g} / \mathrm{L}, p \leq 0.05$ ) (Table 4). Aging ( $t$-value 2.4, $p<0.05)$ remained the only significant determinant for OC at the multiple regression analysis. Only the PROCAM score was associated with BALP $(9.3 \pm 4.7$ versus $10.3 \pm 3.4$ and $7.6 \pm 3.4 \mu \mathrm{g} / \mathrm{L}, p<0.05$ for trend) (Figure 1, panel C).

\subsubsection{CTx and P1NP}

CTx and P1NP levels were significantly lower during DST with respect to the no-DST period $(0.24 \pm 0.14$ versus $0.32 \pm 0.2 \mathrm{ng} / \mathrm{mL}, p \leq 0.05 ; 27 \pm 13.2$ versus $37 \pm 16 \mu \mathrm{g} / \mathrm{L}, p \leq 0.01$, respectively), without showing any other significant correlation with individual cardiovascular risk factors, neither with FRS nor PROCAM (Tables 3 and 4).

\subsubsection{Logistic Analysis for FRS and PROCAM}

For this analysis, OC and BALP were scored according to the 75 th percentile $(16.6 \mathrm{ng} / \mathrm{mL}$ and $9.8 \mu \mathrm{g} / \mathrm{L}$, respectively), while 25(OH)D was scored using the cut-off of $20 \mathrm{ng} / \mathrm{mL}$. After adjustments for obesity and CRP (scored according to the 75th percentile corresponding to $0.3 \mathrm{mg} / \mathrm{dL}$ ), low $25(\mathrm{OH}) \mathrm{D}$ $(\mathrm{OR}(95 \% \mathrm{CI}), 5(1.4-18) p<0.05)$ and elevated OC $(6.7(1.9-23.8) p<0.01)$ levels were found to be significant predictors for FRS, while the finding of elevated OC and/or BAP remained independently associated with PROCAM (3.6 (1.2-10.7), $p<0.05)$.

\section{Discussion}

Our results suggest a significant relationship between $25(\mathrm{OH}) \mathrm{D}, \mathrm{OC}$, and BALP and major CV factors and global risk based on FRS and PROCAM scores in a general adult population.

With regard to individual CV risk factors, our data are in agreement with previous evidences. In particular, $25(\mathrm{OH}) \mathrm{D}$, a recognized factor promoting bone health, retains many other "extraskeletal" actions [1]. In particular, biologically plausible mechanisms related to $\mathrm{CV}$ disease prevention have been identified, while observational studies also suggest an inverse association between serum $25(\mathrm{OH}) \mathrm{D}$ and $\mathrm{CV}$ risk [11]. In fact, $25(\mathrm{OH}) \mathrm{D}$ may modulate hepatic and pancreatic islet function affecting hepatic glucose and lipid metabolism, likely through the activation of $\mathrm{Ca}^{2+} / \mathrm{CaMKK} / \mathrm{AMPK}$ signaling [12]. Moreover, it inhibits renin activity, suppresses the renin-angiotensin-aldosterone system, and affects nitric oxide levels, inflammatory parameters, angiogenesis, platelet aggregation, insulin resistance, and fasting glucose values [12-15]. Recently, another mechanism by which 25(OH)D exerts its beneficial effects has been identified in its capacity to promote antioxidant pathways and cope with oxidative stress and hyperglycemic damage [15]. Accordingly, a recent meta-analysis confirmed the inverse correlation of $25(\mathrm{OH}) \mathrm{D}$ with individual $\mathrm{CV}$ risk factors, including diabetes, hypertension, and dyslipidemia [16].

Generally, 25(OH)D levels vary across the course of the year (3). In the present study, although higher in DST, levels of 25(OH)D did not significantly differ. We enrolled a relatively low number of subjects, including a few subjects in the spring and summer, and as such seasonal variation or month comparison and further inference and explanation of the 25OHD variability, not being focus of the present study, are limited. Nonetheless, we observed a trend showing higher levels at the end of summer and lower levels in winter, which was in agreement with the trend we previously observed in healthy adults [3]. Moreover, as the majority of patients $(78 \%)$ in this cohort presented $25(\mathrm{OH}) \mathrm{D}$ insufficiency or deficiency, the seasonal effect was thought to be minor.

OC, a product of osteoblasts, has attracted much attention as a hormone with close interactions with glucose homeostasis and fat, and it shows the capacity to stimulate islets and fat to secret insulin [2]. In a subgroup of patients, we found a direct correlation between OC and INS, in agreement with previous experimental results, which evidenced that OC can favor normal INS secretion by 
pancreatic $\beta$ cells $[2,17,18]$. Many studies evidenced the relationship between low OC and diabetes and atherosclerosis, including subclinical atherosclerotic biomarkers [2]. Thus, the increase of OC with global risk scores found in our population may appear surprising, considering the inverse relationship of OC with diabetes and obesity indices. However, other authors have reported opposite results, including a higher prevalence of carotid atherosclerosis in healthy post-menopausal women with elevated OC and low BMD, or no correlation $[2,19,20]$. In this scenario, the complexity of the relationship between $\mathrm{OC}$ and $\mathrm{CV}$ disease is evidenced by results showing that elevated OC may also predict CV risk and mortality. In particular, increased OC was found to be involved in the pathogenesis of coronary artery disease in patients with chronic kidney disease. A large cohort study including elderly men (3542 men aged 70-89 years followed for a median of 5.2 years with 198 fatal CV disease events) found the highest CV disease mortality at a high serum OC concentration, as well as in a large cohort of patients at high CV risk (2271 men referred to coronary angiography) [21,22]. In this context, it is critical to consider the relationship with other biomarkers and age-related changes in bone turnover. In fact, we observed an inverse relationship between $25(\mathrm{OH}) \mathrm{D}$ with other BHM, with a positive correlation between the two. Moreover, aging represents an independent factor for 25(OH)D, OC, and BALP in our population. The risk induced by high OC levels could be mediated by arterial calcification, since OC is expressed in calcified atherosclerotic lesions, where it represents a mediator in the calcification process. Accordingly, OC levels strongly correlated with mitral annular calcification in patients with chronic kidney disease [23]. Interestingly, early, highly active endothelial progenitor cells (EPCs), carrying the osteoblastic marker OC, appear to be strongly associated with unstable coronary artery disease suggesting that this particular EPC subset could mediate vascular calcification and abnormal vascular repair and may identify patients with a more unstable phenotype of atherosclerosis [24]. Moreover, a higher percentage of circulating EPCs expressed OC in patients with coronary atherosclerosis compared to subjects with normal endothelial function [25].

There are few data on the relationship between BALP and CV risk. A significant association has been evidenced between BALP and arterial stiffness in pre-dialysis chronic kidney disease [26]. We found higher BALP levels in subjects with dyslipidemia. However, as the role of statins in the reduction of BALP levels has been previously evidenced, we verify the lack of any effect of statin treatment on BALP levels in our population (data not shown) [27]. Data for P1NP and CTx on CV risk, for which we did not find any relationship with CV risk, are even more scarce. Nonetheless, CTx together with OC levels were found to be lower in Type 1 diabetes children than in healthy controls [28]. Moreover, a negative correlation between CTx levels and glycated hemoglobin was observed in diabetic male subjects [29]. In addition, weight-loss has been associated with significant variation in bone formation as well as resorption biomarkers, including OC and CTx [30-34]. Nonetheless, a U-shaped association of CTx levels, together with $\mathrm{OC}$, with CV death and overall mortality was observed in a large cohort of men at high CV risk, suggesting that there may exist an optimum, intermediate range which identifies the highest benefits for both biomarkers [21]. Instead, higher P1NP was associated with higher incidence of myocardial infarction (MI), but not of stroke, whereas CTx was not associated with incident MI or stroke [35]. Thus, the effects of these last biomarkers must be further assessed in other trials and in different populations of patients to assess their potential and significance in specific clinical settings.

Since the relatively low number of subjects enrolled may represent a limitation, a power analysis was performed to test the association between bone turnover biomarkers and CV risk. Thus, according to the method of Sheppard [36], we chose a medium effect size (i.e., a standardized difference) of 0.5, with an $\alpha$ value of 0.05 . The program $G^{*}$ Power 3.1.2 was used for the calculation. The effective power of the study was determined to be 0.99 .

\section{Conclusions}

As we go further into bone and CV physiology, it is evident that a close relationship exists between these conditions. Further studies are needed to investigate potential mechanisms by which 
bone turnover markers are related to metabolic risk and could modulate CV risk. From an holistic perspective, it is conceivable that patients affected by OP likely benefit from CV evaluation, whereas patients with $\mathrm{CV}$ disease would benefit from bone health assessment. Moreover, it will be also interesting to understand how common biological and molecular factors may drive the progression towards a certain pathology and explain why a subject will develop one specific disease rather than another.

Author Contributions: Cristina Vassalle conceived and designed the experiments; Pietro Di Cecco, Maristella Maltinti, Rudina Nreu, Laura Sabatino performed the analysis; Silvia Maffei, Alessandro Pingitore enrolled the subjects, and collected all clinical data; Cristina Vassalle analyzed the data and wrote the paper; Laura Sabatino revised the English style; all authors reviewed and approved the final version of the manuscript.

Conflicts of Interest: The authors declare no conflict of interest.

\section{References}

1. Vassalle, C.; Maffei, S.; Iervasi, G. Bone remodelling biomarkers: New actors on the old cardiovascular stage. In Biomarker Validation-Technological, Clinical and Commercial Aspects, KGaA; Wiley-VCH Verlag GmbH \& Co.: Weinheim, Germany, 2015; Chapter 7; pp. 107-146.

2. Magni, P.; Macchi, C.; Sirtori, C.R.; Corsi-Romanelli, M.M. Osteocalcin as a potential risk biomarker for cardiovascular and metabolic diseases. Clin. Chem. Lab. Med. 2016, 54, 1579-1587. [CrossRef] [PubMed]

3. Bianchi, S.; Maffei, S.; Prontera, C.; Battaglia, D.; Vassalle, C. Preanalytical, analytical (DiaSorin LIAISON) and clinical variables potentially affecting the 25-OH Vitamin D estimation. Clin. Biochem. 2012, 45, 1652-1657. [CrossRef] [PubMed]

4. Vassalle, C.; Pérez-López, F.R. The Importance of Some Analytical Aspects and Confounding Factors in Relation to Clinical Interpretation of Results. In Vitamin D: Daily Requirements, Dietary Sources and Symptoms of Deficiency; Nova Publisher: New York, NY, USA, 2013; Chapter 4; ISBN 978-1-62808-816-8.

5. Iqbal, M.P.; Mehboobali, N.; Azam, I.; Tareen, A.K. Association of alkaline phosphatase with acute myocardial infarction in a population with high prevalence of hypovitaminosis D. Clin. Chim. Acta 2013, 425, 192-195. [CrossRef] [PubMed]

6. Brøndum-Jacobsen, P.; Benn, M.; Jensen, G.B.; Nordestgaard, B.G. 25-Hydroxyvitamin d levels and risk of ischemic heart disease, myocardial infarction, and early death: Population-based study and meta-analyses of 18 and 17 studies. Arterioscler. Thromb. Vasc. Biol. 2012, 32, 2794-2802. [CrossRef] [PubMed]

7. Tomson, J.; Emberson, J.; Hill, M.; Gordon, A.; Armitage, J.; Shipley, M.; Collins, R.; Clarke, R. Vitamin D and risk of death from vascular and non-vascular causes in the Whitehall study and meta-analyses of 12,000 deaths. Eur. Heart J. 2013, 34, 1365-1374. [CrossRef] [PubMed]

8. D'Agostino, R.B.; Vasan, R.S.; Pencina, M.J.; Wolf, P.A.; Cobain, M.; Massaro, J.M.; Kannel, W.B. General cardiovascular risk profile for use in primary care: The Framingham Heart Study. Circulation 2008, 117, 743-753. [CrossRef] [PubMed]

9. Assmann, G.; Cullen, P.; Schulte, H. Simple scoring scheme for calculating the risk of acute coronary events based on the 10-year follow-up of the prospective cardiovascular Münster (PROCAM) study. Circulation 2002, 105, 310-315. [CrossRef] [PubMed]

10. Vassalle, C.; Pagani, F. Biomarkers of Bone Turnover: Potential, Challenges and Pitfalls from the Laboratory Point of view. Rheumatology (Sunnyvale) 2016, 6, 183. [CrossRef]

11. Schnatz, P.F.; Manson, J.E. Vitamin D and cardiovascular disease: An appraisal of the evidence. Clin. Chem. 2014, 60, 600-609. [CrossRef] [PubMed]

12. Leung, P.S. The Potential Protective Action of Vitamin D in Hepatic Insulin Resistance and Pancreatic Islet Dysfunction in Type 2 Diabetes Mellitus. Nutrients 2016, 8, 3. [CrossRef] [PubMed]

13. Mozos, I.; Marginean, O. Links between Vitamin D Deficiency and Cardiovascular Diseases. Biomed. Res. Int. 2015, 2015, 109275. [CrossRef] [PubMed]

14. Papandreou, D.; Hamid, Z.T. The Role of Vitamin D in Diabetes and Cardiovascular Disease: An Updated Review of the Literature. Dis Mark. 2015, 2015, 580474. [CrossRef] [PubMed]

15. Jiménez-Osorio, A.S.; González-Reyes, S.; Pedraza-Chaverri, J. Natural Nrf2 activators in diabetes. Clin. Chim. Acta 2015, 448, 182-192. [CrossRef] [PubMed] 
16. Song, Y.; Wang, L.; Pittas, A.G.; Del Gobbo, L.C.; Zhang, C.; Manson, J.E.; Hu, F.B. Blood 25-hydroxy vitamin D levels and incident type 2 diabetes: A meta-analysis of prospective studies. Diabetes Care 2013, 36, 1422-1428. [CrossRef] [PubMed]

17. Ferron, M.; Hinoi, E.; Karsenty, G.; Ducy, P. Osteocalcin differentially regulates beta cell and adipocyte gene expression and affects the development of metabolic diseases in wild-type mice. Proc. Natl. Acad. Sci. USA 2008, 105, 5266-5270. [CrossRef] [PubMed]

18. Lee, N.K.; Sowa, H.; Hinoi, E.; Ferron, M.; Ahn, J.D.; Confavreux, C.; Dacquin, R.; Mee, P.J.; McKee, M.D.; Jung, D.Y.; et al. Endocrine regulation of energy metabolism by the skeleton. Cell 2007, 130, 456-469. [CrossRef] [PubMed]

19. Montalcini, T.; Emanuele, V.; Ceravolo, R.; Gorgone, G.; Sesti, G.; Perticone, F.; Pujia, A. Relation of low bone mineral density and carotid atheroesclerosis in postmenopausal women. Am. J. Cardiol. 2004, 94, 266-269. [CrossRef] [PubMed]

20. Luo, Y.; Ma, X.; Hao, Y.; Xiong, Q.; Xu, Y.; Pan, X.; Bao, Y.; Jia, W. Relationship between serum osteocalcin level and carotid intima-media thickness in a metabolically healthy Chinese population. Cardiovasc. Diabetol. 2015, 14, 82. [CrossRef] [PubMed]

21. Yeap, B.B.; Chubb, S.A.; Flicker, L.; McCaul, K.A.; Ebeling, P.R.; Hankey, G.J.; Beilby, J.P.; Norman, P.E. Associations of total osteocalcin with all-cause and cardiovascular mortality in older men. Health Men Study Osteoporos. Int. 2012, 23, 599-606. [CrossRef] [PubMed]

22. Lerchbaum, E.; Schwetz, V.; Pilz, S.; Grammer, T.B.; Look, M.; Boehm, B.O.; Obermayer-Pietsch, B.; März, W. Association of bone turnover markers with mortality in men referred to coronary angiography. Osteoporos. Int. 2013, 24, 1321-1332. [CrossRef] [PubMed]

23. Unal, H.U.; Çelik, M.; Gökoğlan, Y.; Çetinkaya, H.; Gök, M.; Karaman, M.; Yilmaz, M.İ.; Eyileten, T.; Oğuz, Y. Mitral annular calcification and the serum osteocalcin level in patients with chronic kidney disease. Ren. Fail. 2014, 36, 1481-1485. [CrossRef] [PubMed]

24. Flammer, A.J.; Gössl, M.; Widmer, R.J.; Reriani, M.; Lennon, R.; Loeffler, D.; Shonyo, S.; Simari, R.D.; Lerman, L.O.; Khosla, S.; et al. Osteocalcin positive CD133+/CD34-/KDR+ progenitor cells as an independent marker for unstable atherosclerosis. Eur. Heart J. 2012, 33, 2963-2969. [CrossRef] [PubMed]

25. Gössl, M.; Mödder, U.I.; Atkinson, E.J.; Lerman, A.; Khosla, S. Osteocalcin expression by circulating endothelial progenitor cells in patients with coronary atherosclerosis. J. Am. Coll. Cardiol. 2008, 52, 1314-1325. [CrossRef] [PubMed]

26. Manghat, P.; Souleimanova, I.; Cheung, J.; Wierzbicki, A.S.; Harrington, D.J.; Shearer, M.J.; Chowienczyk, P.; Fogelman, I.; Nerlander, M.; Goldsmith, D.; et al. Association of bone turnover markers and arterial stiffness in pre-dialysis chronic kidney disease (CKD). Bone 2011, 48, 1127-1132. [CrossRef] [PubMed]

27. Ertugrul, D.T.; Yavuz, B.; Cil, H.; Ata, N.; Akin, K.O.; Kucukazman, M.; Yalcin, A.A.; Dal, K.; Yavuz, B.B.; Tutal, E. STATIN-D study: Comparison of the influences of rosuvastatin and fluvastatin treatment on the levels of 25 hydroxyvitamin D. Cardiovasc. Ther. 2011, 29, 146-152. [CrossRef] [PubMed]

28. Pater, A.; Sypniewska, G.; Pilecki, O. Biochemical markers of bone cell activity in children with type 1 diabetes mellitus. J. Pediatr. Endocrinol. MeTable 2010, 23, 81-86. [CrossRef]

29. Achemlal, L.; Tellal, S.; Rkiouak, F.; Nouijai, A.; Bezza, A.; Derouiche, M.; Ghafir, D.; El Maghraoui, A. Bone metabolism in male patients with type 2 diabetes. Clin. Rheumatol. 2005, 24, 493-496. [CrossRef] [PubMed]

30. Ricci, T.A.; Chowdhury, H.A.; Heymsfield, S.B.; Stahl, T.; Pierson, R.N.; Shapses, S.A. Calcium supplementation suppresses bone turnover during weight reduction in postmenopausal women. J. Bone Miner. Res. 1998, 13, 1045-1050. [CrossRef] [PubMed]

31. Ricci, T.A.; Heymsfield, S.B.; Pierson, R.N.; Stahl, T.; Chowdhury, H.A.; Shapses, S.A. Moderate energy restriction increases bone resorption in obese postmenopausal women. Am. J. Clin. Nutr. 2001, 73, 347-352. [PubMed]

32. Shapses, S.A.; Von Thun, N.L.; Heymsfield, S.B.; Ricci, T.A.; Ospina, M.; Pierson, R.N.; Stahl, T. Bone turnover and density in obese premenopausal women during moderate weight loss and calcium supplementation. J. Bone Miner. Res. 2001, 16, 1329-1336. [CrossRef] [PubMed]

33. Giusti, V.; Gasteyger, C.; Suter, M.; Heraief, E.; Gaillard, R.C.; Burckhardt, P. Gastric banding induces negative bone remodelling in the absence of secondary hyperparathyroidism: Potential role of serum $C$ telopeptides for follow-up. Int. J. Obes. (Lond.) 2005, 29, 1429-1435. [CrossRef] [PubMed] 
34. Hinton, P.S.; LeCheminant, J.D.; Smith, B.K.; Rector, R.S.; Donnelly, J.E. Weight loss-induced alterations in serum markers of bone turnover persist during weight maintenance in obese men and women. J. Am. Coll. Nutr. 2009, 28, 565-573. [CrossRef] [PubMed]

35. Yeap, B.B.; Alfonso, H.; Chubb, S.A.; Byrnes, E.; Beilby, J.P.; Ebeling, P.R.; Allan, C.A.; Schultz, C.; Hankey, G.J.; Golledge, J.; et al. Proportion of Undercarboxylated Osteocalcin and Serum P1NP Predict Incidence of Myocardial Infarction in Older Men. J. Clin. Endocrinol. Metable. 2015, 100, 3934-3942. [CrossRef] [PubMed]

36. Sheppard, C. How large should my sample be? Some quick guides to sample size and the power of tests. Mar. Pollut. Bull. 1999, 38, 439-447. [CrossRef]

(C) 2017 by the authors. Licensee MDPI, Basel, Switzerland. This article is an open access article distributed under the terms and conditions of the Creative Commons Attribution (CC BY) license (http://creativecommons.org/licenses/by/4.0/). 